\title{
NOTIFICATION OF 6442 CASES OF BONE TUBERCULOSIS IN BRAZIL: EPIDEMIOLOGICAL PROFILE FROM 2009 TO 2018
}

\author{
NOTIFICAÇÃO DE 6442 CASOS DE TUBERCULOSE ÓSSEA NO BRASIL: PERFIL \\ EPIDEMIOLÓGICO DE 2009 A 2018
}

\section{NOTIFICACIÓN DE 6442 CASOS DE TUBERCULOSIS ÓSEA EN BRASIL: PERFIL EPIDEMIOLÓGICO DE 2009 A 2018}

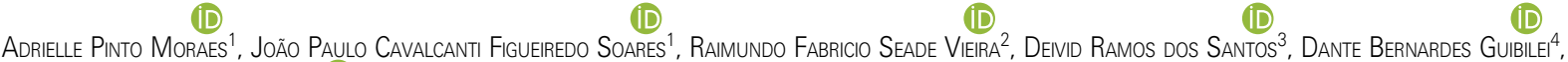 \\ Marcio Olivelra Penna de Carvalmo ${ }^{4}$ \\ 1. Universidade do Estado do Pará, Hospital Porto Dias (UEPA/HPD), Belém, PA, Brazil. \\ 2. Hospital Metropolitano de Urgência e Emergência (HMUE), Belém, PA, Brazil. \\ 3. Universidade do Estado do Pará, Experimental Surgery Laboratory (LCE/UEPA), Belém, PA, Brazil. \\ 4. Hospital Adventista de Belém, PA, Brazil.
}

\begin{abstract}
Objective: To analyze the occurrence of notified cases of bone tuberculosis in Brazil during the period from 2009 to 2018. Methods: Quantitative, descriptive and retrospective study. The data consisted of cases reported to the Notifiable Diseases Information System (SINAN) of DATASUS. To analyze the results, the non-parametric statistical Chi-squared and G tests, capable of expressing statistical associations, were used. Results: 6,442 cases of bone tuberculosis were reported in Brazil, with an average of 644.2 cases per year. The Southeast was responsible for $41.5 \%$ of the cases $(n=2676)$. The extrapulmonary form accounted for $87.9 \%$ (5661). There was a predominance in males $(66.1 \%, n=4258)$, Whites $(41.6 \%, n=2678)$ and in the above 35 years of age group $(73.9 \%, n=4757)$. In the data collected, the risk factor data was not correctly filled out, making reliable statistical associations impossible in this study, mainly between alcoholism, tobacco use, AIDS, diabetes, mental illness, illicit drug use and homelessness. Conclusion: There was greater notification of cases of bone tuberculosis in the Southeast and Northeast regions of Brazil, which predominantly affected young, economically productive men. Tuberculosis has a correlation with diabetes, HIV / AIDS, smoking and alcohol and drug use, according to the results of this study. Level of evidence II; Retrospective, analytical, quantitative and descriptive study.
\end{abstract}

Keywords: Epidemiology; Tuberculosis, Osteoarticular; Bone Tuberculosis; Orthopedics; Pott's Disease.

\section{RESUMO}

Objetivo: Analisar a ocorrência de casos de tuberculose óssea notificados no Brasil entre o período de 2009 a 2018. Métodos: Estudo quantitativo, descritivo e retrospectivo. Os dados consistiram em casos notificados no Sistema de Informação de Agravos de Notificação (SINAN) do DATASUS. Para análise dos resultados, foram usados testes estatísticos não paramétricos, Qui-quadrado e teste G, capazes de expressar associação estatística. Resultados: Foram notificados 6.442 casos de tuberculose óssea no Brasil, com média de 644,2 casos por ano. O Sudeste foi responsável por 41,5\% dos casos $(n=2676)$. A forma extrapulmonar correspondeu a 87,9\% (5.661). Houve predomínio no sexo masculino $(66,1 \%, n=4258)$, em brancos $(41,6 \%, n=2678)$ e maiores de 35 anos $(73,9 \%, n=4757)$. Os dados coletados não tinham preenchimento correto dos fatores de risco, o que impossibilitou a associação estatística confiável neste estudo, principalmente entre alcoolismo, tabagismo, AIDS, diabetes, doença mental, uso de drogas ilícitas e moradores de rua. Conclusões: Houve maior notificação de casos de tuberculose óssea no Sudeste e no Nordeste do Brasil, que afetou predominantemente homens jovens e em plena atividade econômica. A tuberculose tem correlação com diabetes, HIVIAIDS, tabagismo e uso de álcool e drogas ilícitas, conforme os resultados deste estudo. Nível de evidência II; Estudo retrospectivo, analítico, quantitativo e descritivo.

Descritores: Epidemiologia; Tuberculose Osteoarticular; Tuberculose Óssea; Ortopedia, Doença de Pott.

\section{RESUMEN}

Objetivo: Analizar la ocurrencia de casos de tuberculosis ósea notificados en Brasil en el período de 2009 a 2018. Métodos: Estudio cuantitativo, descriptivo y retrospectivo. Los datos consistieron en casos notificados en el Sistema de Información de Enfermedades de Notificación (SINAN) del DATASUS. Para análisis de los resultados, fueron usados tests estadísticos no paramétricos, Chi-cuadrado y test G, capaces de expresar asociación estadística. Resultados: Fueron notificados 6.442 casos de tuberculosis ósea en Brasil, con promedio de $644,2$ casos por año. El sudeste fue responsable por 41,5\% de los casos ( $n=2676)$. La forma extrapulmonar correspondió a 87,9\% (5661). Hubo predominio en el sexo masculino (66,1\%, $n=4258)$, en blancos (41,6\%, $n=2678$ ) y mayores de 35 años (73,9\%, $n=4757)$. Los

Study conducted at the Experimental Surgery Laboratory - Universidade do Estado do Pará (LCE - UEPA), Travessa Perebebuí, 2623, Bairro do Marco, Belém, Pará, Brazil.

Correspondence: Deivid Ramos dos Santos. Rua Passagem Maciel, 120, Bengui, Belém, PA, Brasil.66630-210. deivid ramos45@hotmail.com 
datos colectados no tenían llenado correcto de los factores de riesgo, lo que imposibilitó la asociación estadística confiable en este estudio, principalmente entre alcoholismo, tabaquismo, SIDA, diabetes, enfermedad mental, uso de drogas ilícitas y personas sin techo. Conclusiones: Hubo mayor notificación de casos de tuberculosis ósea en el sudeste y en el noreste de Brasil, que afectó predominantemente a hombres jóvenes y en plena actividad económica. La tuberculosis tiene correlación con diabetes, VIH/SIDA, tabaquismo y uso de alcohol y drogas ilícitas, conforme a los resultados de este estudio. Nivel de evidencia II; Estudio retrospectivo, analítico, cuantitativo y descriptivo.

Descriptores: Epidemiología; Tuberculosis Osteoarticular; Tuberculosis Ósea; Ortopedia; Enfermedad de Pott.

\section{INTRODUCTION}

Tuberculosis (TB) is a serious public health problem, especially in underdeveloped countries where health care services do not have full problem-solving capacity. ${ }^{1,2}$

It is an infectious disease caused by the bacillus Mycobacterium tuberculosis and can affect any physiological system, with pulmonary tuberculosis (PTB) being the most frequent form. After respiratory infection, the bacillus can spread to various other organs, characterizing extrapulmonary tuberculosis (EPTB). ${ }^{3}$

Bone EPTB was first described in 1779 by Dr. Percivall Pott, one of the founders of orthopedics, and for this reason it is also known as Pott's disease when it presents as spondylodiscitis, the most common. ${ }^{3,4}$ If can be triggered by the spread of the bacillus hematogenously or through proximity to regional lymph nodes affected by caseous necrosis.

The spine, the peripheral joints and the bone diaphyses are the most frequent sites of involvement. This form of TB is responsible for approximately $5 \%$ of all registered tuberculosis cases and can cause serious complications related to postural support and also severe neurological changes. ${ }^{3,5}$

Despite the great impact, there is still no consensus around the surgical therapeutic approach, mainly due to the almost total lack of studies on the topic, ${ }^{4,5}$ especially in Brazil, a continental country and among the 20 countries with the highest rates of the disease in the world. ${ }^{6}$

The diagnosis is complex, in view of the difficulty in visualizing the affected tissue and also because most of the lesions are paucibacillary. ${ }^{7,8}$ Recently, EPTB has gained attention in epidemiological studies, considering the increase in its incidence and its relationship with the growth in HIV/AIDS cases in the world. ${ }^{9}$

Nonetheless, only one article of an epidemiological nature, published in 1994 and covering a limited region of Brazil, was found that included an epidemiological profile of bone TB. ${ }^{8}$ Thus, it is essential to conduct new studies on this topic, with the scope and specificity to support case identification, especially in population groups at risk, making early detection possible, minimizing complications and aiming to increase therapeutic success.

Thus, this study seeks to identify the epidemiology profile of bone tuberculosis cases reported in Brazil during the period between 2009 and 2018.

\section{METHODS}

This is a quantitative, retrospective, descriptive study, conducted by collecting database information posted to the Notifiable Diseases Information System (SINAN), made available by DATASUS, referring to cases of bone tuberculosis registered between 2009 and 2018.

The data were grouped in tables and categorized by variables of age, sex, race/color, education level, form of the disease, risk factors and macro-region of residence. Analysis was conducted by means of non-parametric Chi-squared statistical tests to express association between the variables. The Biostat 5.4 program was used, observing a p-value < 0.05. Confidence intervals were constructed based on the proportion of cases. Finally, 95\% confidence intervals were adopted in all calculations.

The Tabwin 4.53 program, made available by the Ministry of $\mathrm{He}$ alth, was used to put together a procedure distribution map by state. It was not necessary to submit this study to the Institutional Review Board (IRB) because it was using data from public domain databases. There was no description of the sites of bone involvement reported.

\section{RESULTS}

Between 2009 and 2018, 6,442 cases of bone tuberculosis (BTB) were reported in Brazil. The Southeast region was responsible for $41.5 \%(n=2,676)$ of the cases, followed by the Northeast $(29.2 \%$, $n=1,879)$ and the South $(14.7 \%, n=975)$. The number of ignored cases for this variable was $0.2 \%(n=12)$. The mean cases reported per year was 644.2, the lowest value in $2016(n=602)$ and the highest value in 2009 ( $n=672)$, as can be seen in Table 1.

Of all the cases reported, $12.1 \%(n=781)$ were of the pulmonary form and the rest $(n=5,661)$ were extrapulmonary. (Table 2) We observed an increase in the number of cases proportional to age, with the highest peak between 45 and 54 years of age. There was higher incidence among males $(66.2 \%, n=4,258)$ and among individuals with few years of education. There was higher occurrence in Whites $(41.6 \%, n=2,678)$, followed by mixed race individuals $(38.2 \%, n=2,461)$. The fact that the education level and race variables have high numbers of ignored cases, 32.1\% $(n=2,071)$ and $8.8 \%(n=566)$, respectively, stands out.

We observed that $84.7 \%(n=5,458)$ did not have alcoholism as a risk factor, $44.8 \%(n=2,886)$ were not tobacco users. These variables were ignored in 556 (8.6\%) and 3,292 (51.5\%) cases, respectively.

As regards HIV/AIDS, $75.5 \%$ did not have the syndrome, while this information was ignored in $14.6 \%(n=944)$ of the patients. Eighty-two and a half percent $(82.5 \%, n=5,319)$ were diabetics and 89.6\% $(n=5,773)$ were not mentally ill.

In relation to illicit drug use, this information was ignored in $51.2 \%$ $(n=3,302)$ of the patients and $47.1 \%$ of the patients reported no drug abuse. Regarding housing, 47.6\% were not homeless, 43 patients $(1.6 \%)$ were living in the street and $51.6 \%(n=3,330)$ did not have this information filled in, as can be observed in Table 3.

\section{DISCUSSION}

Bone tuberculosis is triggered by the spread of $M$. tuberculosis hematogenously or through proximity to lymph nodes affected by caseous necrosis. ${ }^{7-11}$ In Brazil, during the period studied, 41.5\%

Table 1. Distribution of notified cases of bone tuberculosis in Brazil by region, between the years of 2009 and 2018. Pará, 2020.

\begin{tabular}{|c|c|c|c|c|c|c|c|c|c|c|c|c|}
\hline Region & 2009 & 2010 & 2011 & 2012 & 2013 & 2014 & 2015 & 2016 & 2017 & 2018 & Total & $\%$ \\
\hline North & 56 & 42 & 63 & 62 & 54 & 60 & 65 & 50 & 60 & 57 & 569 & 8.8 \\
\hline Southeast & 255 & 255 & 257 & 264 & 241 & 283 & 299 & 271 & 276 & 275 & 2676 & 41.5 \\
\hline Central-West & 42 & 47 & 30 & 41 & 30 & 29 & 35 & 26 & 38 & 43 & 361 & 5.6 \\
\hline Ignored & 1 & - & - & - & 3 & - & - & 4 & 1 & 3 & 12 & 0.2 \\
\hline Total & 672 & 608 & 641 & 670 & 628 & 682 & 670 & 602 & 631 & 638 & 6.442 & 100.0 \\
\hline
\end{tabular}

$x^{2}$ test $=<0.0001$. Source: Ministry of Health/SVS - Notifiable Diseases Information System - Sinan Net. 
Table 2. Distribution of notified cases of bone tuberculosis in Brazil by form, age group, sex, education level and race between the years of 2009 and 2018. Pará, 2020.

\begin{tabular}{|c|c|c|c|c|}
\hline Variables & & $\mathbf{N}$ & $\%$ & p-value \\
\hline \multirow{2}{*}{ Form } & Extrapulmonary & 5,661 & 87.9 & \multirow{2}{*}{$<0.001$} \\
\hline & Pulmonary & 781 & 12.1 & \\
\hline \multirow{7}{*}{ Age group } & 0 to 14 years & 375 & 5.8 & \multirow{7}{*}{$<0.001$} \\
\hline & 15 to 24 years & 420 & 6.5 & \\
\hline & 25 to 34 years & 890 & 13.8 & \\
\hline & 35 to 44 years & 1,095 & 17.0 & \\
\hline & 45 to 54 years & 1,295 & 20.1 & \\
\hline & 55 to 64 years & 1,228 & 19.1 & \\
\hline & 65 or + & 1,139 & 17.7 & \\
\hline \multirow{3}{*}{ Sex } & Male & 4,258 & 66.1 & \multirow{2}{*}{$>0.05$} \\
\hline & Female & 2,184 & 33.9 & \\
\hline & illiterate & 244 & 3.8 & \multirow{6}{*}{$<0.005$} \\
\hline \multirow{5}{*}{ Education Level } & 1st to 4 th grade & 1,129 & 17.5 & \\
\hline & 5th to 8th grade & 1,254 & 19.5 & \\
\hline & High school & 1,202 & 18.7 & \\
\hline & College & 542 & 8.4 & \\
\hline & Ignored or not applicable & 2,071 & 32.1 & \\
\hline \multirow{6}{*}{ Race } & White & 2,678 & 41.6 & \multirow{6}{*}{$<0.001$} \\
\hline & Black & 635 & 9.9 & \\
\hline & Yellow & 61 & 0.9 & \\
\hline & Brown & 2,461 & 38.2 & \\
\hline & Indigenous & 41 & 0.6 & \\
\hline & Ignored & 566 & 8.8 & \\
\hline \multicolumn{2}{|r|}{ TOTAL } & 6.442 & 100.0 & \\
\hline
\end{tabular}

Source: Ministry of Health/SVS - Notifiable Diseases Information System - Sinan Net.

Table 3. Distribution of notified cases of bone tuberculosis in Brazil by risk factor between the years of 2009 and 2018. Pará, 2020.

\begin{tabular}{|c|c|c|c|c|}
\hline \multicolumn{2}{|c|}{ Risk factors } & \multirow{2}{*}{$\begin{array}{c}\mathbf{n} \\
428\end{array}$} & \multirow{2}{*}{$\begin{array}{c}\% \\
6.6\end{array}$} & \multirow[t]{2}{*}{ p-value } \\
\hline \multirow{3}{*}{ Alcoholism } & Yes & & & \\
\hline & No & 5458 & 84.7 & $<0.001$ \\
\hline & Ignored & 556 & 8.6 & \\
\hline \multirow{3}{*}{ Tobacco use } & Yes & 264 & 4.1 & \\
\hline & No & 2886 & 44.8 & $<0.001$ \\
\hline & Ignored & 3292 & 51.1 & \\
\hline \multirow{3}{*}{ AIDS } & Yes & 631 & 9.8 & \multirow{3}{*}{$<<0.005$} \\
\hline & No & 4867 & 75.5 & \\
\hline & Ignored & 944 & 14.6 & \\
\hline \multirow{3}{*}{ Diabetes } & Yes & 582 & 9.0 & \\
\hline & No & 5319 & 82.5 & $<0.001$ \\
\hline & lgnored & 541 & 8.4 & \\
\hline \multirow{3}{*}{ Mental illness } & Yes & 106 & 1.6 & \multirow{3}{*}{$<0.001$} \\
\hline & No & 5773 & 89.6 & \\
\hline & Ignored & 563 & 8.7 & \\
\hline \multirow{3}{*}{ Illicit drugs } & Yes & 105 & 1.6 & \multirow{3}{*}{$<0.001$} \\
\hline & No & 3035 & 47.1 & \\
\hline & lgnored & 3302 & 51.2 & \\
\hline \multirow{3}{*}{ Homelessness } & Yes & 43 & 0.6 & \multirow{3}{*}{$<0.001$} \\
\hline & No & 3069 & 47.6 & \\
\hline & lgnored & 3330 & 51.6 & \\
\hline \multicolumn{2}{|c|}{ TOTAL } & 6442 & 100.0 & \\
\hline
\end{tabular}

Source: Ministry of Health/SVS - Notifiable Diseases Information System - Sinan Net. of the 6,442 cases were concentrated in the Southeast region $(n=2,676)$, which can be explained by better access to specialized health services for conducting diagnosis and its subsequent (and proper) notification. In addition, this region has great demographic density compared to the others, consequently increasing the absolute number of cases of pulmonary and extrapulmonary tuberculosis. ${ }^{8}$

Unlike pulmonary tuberculosis, which has had a declining rate in Brazil in recent years, bone tuberculosis has had a consistent trend of approximately $641( \pm 27.9)$ cases annually. This permits us to assume that the actions to prevent and fight tuberculosis, such as contact tracing, conducting directly observed treatment and adequate treatment aimed at reducing the cycle of transmission of the disease, have not fully achieved the goal of reducing cases of bone tuberculosis in Brazil. This is due to the diagnostic complexity and the need for imaging and laboratory examinations that are not available in the primary healthcare network, delaying case identification and diagnosis. 8,11

Only $12.1 \%(n=781)$ of cases have the concomitant pulmonary form. The higher occurrence of the extrapulmonary form $(87.9 \%$, $\mathrm{n}=5,661$ ) makes diagnosis using the more accessible methods difficult, since most of the lesions are paucibacillary, i. e., are not identified by the AARB test. ${ }^{7}$ This makes diagnosis more complex, especially in locations more distant from metropolitan regions and without access to the necessary treatments. This creates case subnotification and subinformation, underestimating the real infection rate in locations far from Brazilian capitals. ${ }^{12}$

The heterogeneity of its clinical forms and the difficulty in early diagnosis usually cause impactful delays in the success of the treatment and, therefore, lead to a degree of physical disability. ${ }^{2,5}$ It is known that imaging tests do not have high specificity. Radiography is the most-used imaging examination, but it may not detect a bone lesion in the initial phase of infection. The most identified lesions are expansive processes, erosion and the formation of sequestra in some cases. ${ }^{9,10}$ Computed tomography and magnetic resonance can identify lesions earlier, but they are expensive diagnostic methods that are not available in all public services in Brazil. Bone biopsy has important diagnostic value, because in addition to enabling the detection of granulomas, it allows sensitivity and antituberculosis therapy resistance tests to be performed.

In this context, a detailed anamnesis is essential for the formulation of a diagnostic hypothesis, considering the possibility of previous contact with an individual with tuberculosis for the correct management of the patient with a suggestive radiograph.

It is known, however, that the Brazilian primary healthcare system has the technical and structural conditions to track, diagnose and provide early treatment to individuals affected by the pulmonary form through primary healthcare throughout the national territory, encompassing almost $90 \%$ of pulmonary tuberculosis cases. Despite the reduction in this form of involvement in recent years, it is still important to define policies and articulate intersectoral actions to prevent complications, such as bone tuberculosis, which often develops permanent sequelae. ${ }^{13,14}$

There was higher incidence among males $(66.1 \%, n=4,258)$, possibly because they are more exposed to risk factors such as alcoholism, tobacco use and HIV, a pattern found nationwide. ${ }^{15}$ We observed a greater predominance among individuals with a low education level, a fact also reported in patients with the pulmonary form by several studies. The low education level is a determining factor for increased social vulnerability of the individual, increased possibility of exposure, less prevention of contact with bacilliferous patients, for the development of the disease and abandonment of treatment. ${ }^{15,16}$

A higher incidence was noted among Whites, followed by individuals of mixed race, as found in studies of the epidemiological profile of pulmonary tuberculosis. ${ }^{14,15}$ It is noteworthy that the education level and race/color variables have high numbers of ignored cases, decreasing the reliability of the statistical data. Nevertheless, it is possible to set goals to improve notification quality and support new studies on the topic. ${ }^{12}$ 
Regarding risk factors, $9.8 \%$ of the patients had HIV/AIDS $(n=631), 4.1 \%(n=264)$ smoked, 6.6\% $(n=428)$ were alcohol users and $9 \%(n=582)$ had diabetes. It is important to note that diabetic patients have a higher risk of latent tuberculosis developing into active tuberculosis, with a risk of progression from initial infection 2.44 to 8.33 times higher in patients with DM than in those without the disease. ${ }^{16,17}$ The mortality rate associated with tuberculosis is 9 times higher in smokers that in non-smokers. Likewise, there is a greater chance of complications in individuals who use illicit drugs. ${ }^{18,19}$

Patients coinfected with HIV/AIDS are at increased risk of death. It is known that a third of HIV-related deaths are due to TB. ${ }^{18,19}$ It also favors the onset of EPTB. The data for variables related to risk factors were incomplete, making statistical association difficult and demonstrating the real need to improve promotion of the SINAN database. ${ }^{12}$

Furthermore, specific studies are suggested in order to show the most frequent location of bone tuberculosis, the evolution of treatment and diagnostic methods. The percentage found of several variables ignored in the information system is a study bias. Even so, the information found can support the formulation of strategies to reduce and prevent the rates of bone tuberculosis in Brazil.

\section{CONCLUSION}

There was a higher concentration of notified cases of bone tuberculosis in the Southeast of the country. It predominantly affects young working males with a low education level. Tuberculosis has a significant correlation with diabetes, HIV/AIDS, and tobacco, alcohol and drug use.

All authors declare no potential conflict of interest related to this article.

CONTRIBUTION OF THE AUTHORS: Each author made significant individual contributions to this manuscript. APM: data analysis, writing of the discussion and preparation of the entire research project; JPCFS: writing, revision and intellectual concept; RFSV: statistical analysis, methodology and review; DRS: data analysis and review; DBG: writing of the discussion and review; MOPC: data acquisition and interpretation, writing of the discussion.

\section{REFERENCES}

1. Sumer NS, Dinesh RS, Trishna RS, Wilfred CGP. Tuberculous Osteomyelitis and Spondylodiscitis. Semin musculoskelet radiol. 2011;15(5):446-58. doi: 10.1055/s-00311293491

2. Shaun KM, Anne-Marie D, Ray L, Lisa GPI, Ryan JG, lan K. Epidemiology and Clinical Management of Tuberculosis in Children in Canada. Paediatr Child Health. 2015;20(2):83-8. doi 10.1093/pch/20.2.83

3. Lola DP, Jean-Paul J, Omar K, Alain BY, Isabelle F. Bone Tuberculosis: When Consider This Diagnosis? Rev Med Suisse. 2016;12(504):262-5.

4. Puertas EB, Chagas JCM, Wajchenberg M, D'orto CCC. Avaliação clínica, radiológica e tratamento de 17 pacientes com tuberculose óssea na coluna vertebral. Rev Bras Ortop. 1999:34(2):113-6

5. Trecarichi EM, Di Meco E, Mazzotta V, Fantoni M. Tuberculous Spondylodiscitis: Epidemiology, Clinical Features, Treatment, and Outcome. Eur Rev Med Pharmacol Sci. 2012;16 Suppl 2:58-72

6. Barreira D. Os desafios para a eliminação da tuberculose no Brasil. Epidemiol. Serv. Saude. 2018;27(1):e00100009. doi:10.5123/S1679-49742018000100009.

7. Faroug R, Psyllakis P, Gulati A, Makvana S, Pareek M, Mangwani J. Diagnosis and Treatment of Tuberculosis of the Foot and ankle-A Literature Review. Foot (Edinb). 2018;37:105-12. doi: 10.1016/j.foot.2018.07.005.

8. Pietrobon RS, Pinha MA, Costa PAB, Silva RF. Epidemiologia da tuberculose óssea: análise de 149 casos no Paraná. Rev Bras Ortop. 1994;29(6)

9. Vicente PG. Infectious Spondylitis. Enferm Infecc Microbiol. Clin. 2008;26(8):510-7.

10. Jain M, Sarkar S, Naik S, Behera S. lliac Bone Tuberculosis With Bicompartmental Abscess. BMJ Case Rep. 2018;2018:bcr2018226606. doi: 10.1136/bcr-2018-226606.

11. Dapunt U, Mischnik A, Goeppinger S, Lehner B. A Persistent Case of Tuberculosis of the Pu- bic Symphysis and Pubic Bone. BMJ Case Rep. 2014;2014:bcr2013203456. doi: 10.1136/ bcr-2013-203456

12. Santos DR, Giubilei DB, Carvalho MOP, Teixeira ES, Gomes RL, Moraes AP. Epidemiology and mortality of thoracolumbosacral spinal arthrodesis in brazil: the last 10 years. Coluna/Columna. 2020;19(2):120-2. doi: 10.1590/s1808-185120201902218933.

13. Barros PG, Pinto ML, Silva TC, Silva EL, Figueiredo TMRM. Perfil Epidemiológico dos casos de Tuberculose Extrapulmonar em um município do estado da Paraíba, 2001-2010. Cad. Saúde Colet. 2014;22(4):343-50. doi: 10.1590/1414-462X201400040007.

14. Tan LY, Loi HY, Agrawal S, Hallinan JTPD.A Case of Tuberculous Infection of the Talus Misdiagnosed as Gout. J Clin Rheumatol. 2020;26(7):e272-4. doi: 10.1097/ RHU.0000000000001122.

15. Sebben AL, Dotta G, Oliveira AEL, Schneider RLM, Sebben MA, Roso V. Tuberculose de articulação coxofemoral: a propósito de um caso. Rev Assoc Med Bras. 2012;58(1):15-7 doi: 10.1590/S0104-42302012000100008

16. Arathi N, Ahmad F, Huda N. Osteoarticular tuberculosis-a three years' retrospective study. J Clin Diagn Res. 2013;7(10):2189-92. doi: 10.7860/JCDR/2013/6859.3467.

17. Muñoz-Torrico M, Caminero-Luna J, Migliori GB, D’Ambrosio L, Carrillo-Alduenda JL, Villareal-Velarde H, et al. Diabetes is Associated with Severe Adverse Events in Multidrug-Resistant Tuberculosis. La diabetes se asocia con reacciones adversas graves en la tuberculosis multirresistente. Arch Bronconeumol. 2017;53(5):245 $\square 50$. doi: 10.1016/j.arbres.2016.10.021.

18. Lönnroth K, Williams B, Stadlin S, Jaramillo E, Dye C. Alcohol use as a risk factor for tuberculosis - a systematic review. BMC Public Health. 2008;8:289. doi: 10.1186/1471-2458-8-289.

19. Soh AZ, Chee CBE, Wang YT, Yuan JM, Koh WP. Alcohol drinking and cigarette smoking in relation to risk of active tuberculosis: prospective cohort study. BMJ Open Respir Res. 2017;4(1):e000247. doi:10.1136/bmjresp-2017-000247 